\title{
PENGGUNAAN REGISTER BERUPA NOMINA DI KALANGAN PEDAGANG TRADISIONAL PASAR TERAPUNG KOTA BANJARMASIN
}

\author{
Dana Aswadi dan Erni Susilawati
}

\author{
STKIP-PGRI Banjarmasin \\ Jln. Sultan Adam Kompleks H. Iyus, No. 18 RT. 23 Banjarmasin, \\ Kode Pos 70121. \\ e-mail: dadan899@yahoo.co.id
}

\begin{abstract}
Abstrak
Penelitian ini bertujuan untuk mengaflikasikan keilmuan kajian sosiolinguistik, yaitu menggambarkan penggunaan register di kalangan pedagang pasar terapung di kota Banjarmasin dan menjelaskan makna register di kalangan pedagang pasar terapung di kota Banjarmasin. Target khusus dari penelitian ini adalah agar ilmu linguistik khususnya kajian sosiolinguistik yang membahas antardisiplin ilmu, yaitu sosiologi dan linguistik bisa lebih dipahami oleh para pembaca. Bahkan, pelaksanaan penelitian dengan menggunakan kajian ilmu tersebut dalam penggunaan register di kalangan pedagang pasar terapung akan menjadi salah sumbangan ilmu dalam bidang linguistik yang juga berguna untuk lebih memperkenalkan fenomena bahasa serta budaya yang ada di pasar terapung kota Banjarmasin. Selanjutnya, penelitian ini juga ditargetkan dimuat dalam jurnal ilmiah, baik skala nasional maupun internasional nantinya.

Metode yang digunakan dalam penelitian ini adalah metode deskriptif kualitatif dengan pendekatan kajian sosiolinguistik. Metode hermeneutik juga digunakan dalam memahami makna pada teks percakapan. Metode ini menggambarkan penggunaan register di kalangan pedagang pasar terapung di kota Banjarmasin dengan kajian sosiolinguistik. Penelitian ini juga akan menerapkan beberapa teknik dalam pemerolehan data yang akurat, yaitu menggunakan teknik rekaman, yaitu merekam fenomena bahasa yang terjadi di kalangan pedagang pasar terapung di kota Banjarmasin, kemudian melakukan pencatatan (catat simak) sebagai salah satu cara untuk mencatat kosakatanya, kemudian triangggulasi, dan tidak ketinggalan menggunakan teknik observasi. Dengan metode tersebut, penelitian tentang penggunaan register di kalangan pedagang pasar terapung di kota Banjarmasin akan memiliki data yang akurat dan bisa dipertanggungjawabkan.

Hasil penelitian ini adalah ditemukannya gambaran penggunaan register bentuk nomina.
\end{abstract}

Kata Kunci: register, nomina

\section{Pendahuluan}

Manusia tidak terlepas dari berbagai aktifitas yang melibatkan bahasa sebagai sarananya dalam setiap aktfitas sosial. Alwasilah (1993:8) mengungkapkan bahwa dalam sosiologi ada disebut istilah gregarousness yang berarti naluri manusia untuk selalu hidup bersama orang lain, maka manusia disebut social animal atau hewan sosial. Jadi, manusia tidak terlepas dengan keadaan sosial dengan melibatkan bahasa dalam setiap komunikasinya. Bahasa sebagai sarana menjadi alat penyampaian informasi, berita, pengungkapan rasa bahagia, sedih, dan yang lainnya. Bahasa digunakan sebagai alat untuk berinteraksi antara satu dengan yang lainnya. Hal ini disampaikan oleh Chaer (2010:14) yang menyatakan bahwa bahasa merupakan sebuah sistem lambang bunyi yang bersifat arbitrer yang digunakan manusia sebagai alat komunikasi atau alat interaksi sosial. 
Menurut Kridalaksana (2011:24) menyatakan bahwa bahasa adalah sistem lambang bunyi yang arbitrer dan dipergunakan oleh suatu masyarakat untuk bekerja sama, berinteraksi, dan mengidentifikasi diri. Bahkan, bahasa menjadi sarana dalam berbagai aspek kehidupan, diantaranya dalam ranah sosial masyarakat. Jadi, bahasa menjadi sarana bagi manusia untuk menyampaikan berbagai keperluan dengan berbagai bidang yang menyertainya. Oleh karena itu, bahasa sebagai sarana komunikasi dengan berbagai fenomena kebahasaan memasuki berbagai aspek kehidupan sosial masyarakat.

Bahasa selalu menjadi hal yang menarik untuk diteliti. Bahasa memiliki ’berbagai macam variasidengan berbagai fenomena kebahasaan.Hal ini senada dengan apa yang telah disampaikan oleh Andersen (2001:3) bahwa variation can be described with respect to linguistic 'variasi bahasa dapat dijelaskan berkenaan dengan fenomena linguistik'. Variasi bahasa ini terjadi dikarenakan setiap masyarakat memiliki bahasa yang digunakan sendiri sehingga bahasa yang digunakan memiliki perbedaan dengan masyarakat lainnya. Variasi bahasa ini menjadi satu ukuran untuk penggunanya dalam mengaflikasikan bahasa dalam tataran sosial sesuai dengan keperluannya. Jadi, variasi bahasa merupakan hal yang sangat perlu diperhatikan karena dia berada pada tataran sosial dan memilki keperluan. Ada berbagai macam variasi dalam penggunaan bahasa. Macam-macam variasi ini dihubungkan dengan pemakai bahasa dan dihubungkan juga dengan situasi pemakaian bahasa.

Register berkenaan dengan pengguna bahasa yang dihubungkan dengan konteks bahasa. Permasalahan register menarik untuk diteliti dikarenakan dalam kehidupan biasanya memiliki berbagai macam register, terutama dikarenakan banyaknya kegiatan yang dilakukan oleh pengguna bahasa sendiri, misalnya di kota dan desa. Apabila melihat register di kota, maka akan ditemui berbagai macam register, yaitu kegiatan yang dilakukan pengguna ada bermacam-macam, misalnya register pegawai Bank atau register orang yang transaksi di Bank (nasabah) maka akan menggunakan bahasa perbankan. Register pedagang, maka penyesuaian konteks pasar yang digunakan, artinya dia akan menggunakan bahasa perdagangan. Bahkan, register pedagang pun memiliki kekhasan dalam penggunaan bahasa tergantung dari apa yang di jual maupun dibeli, serta situasi dan kondisinya (transaksi jual-beli).Pedagang tersebut menggunakan bahasa daerah (bahasa Banjar) dalam setiap terjadi komunikasi. Hal tersebut senada dengan apa yang disampaikan oleh Baryadi (2014:31) bahwa bahasa daerah adalah bahasa yang dipakai sebagai bahasa perhubungan intra daerah atau intra masyarakat disamping bahasa Indonesia dan dipakai sebagai pendukung sastra serta budaya daerah atau masyarakat etnik di wilayah Republik Indonesia. Berkenaan bahasa daerah yang digunakan sebagai alat komunikasi juga disampaikan oleh Tofa (2013:1) bahasa daerah digunakan untuk berkomunikasi dalam berhubungan dalam lingkungan keluarga maupun dalam 
masyarakat bahasa daerah itu sendiri berada.Oleh karena itu, transaksi jual beli menggunakan bahasa daerah. Lihat contoh transaksi jual beli berikut.

Penjual : "Ikam handak nukar apa?” (Kamu ingin membeli apa?)

Pembeli : "Wadai gambung tu barapa cil haraganya" (Roti itu berapa harganya,bu?)

Penjual : "Lima ribu sabuting" (Lima ribu satu)

Pembeli: “Geh, sabuting cil ai. Tukar cil lah!” (Geh, satu bu. Tukar dulu $\mathrm{bu})$

Penjual : "Jual". (Jual)

Percakapan diatas menunjukkan bahwa terdapat register bentuk nomina di kalangan pedagang, yaitu kata sabuting (satu buah). Hal tersebut merupakan fenomena bahasa yang sering terjadi antara pembeli dan penjual. Percakapan tersebut terdapat percakapan kata sabuting yang menunjukkan nomina.

Fenomena bahasa domain perdagangan yang sangat menarik adalah fenomena bahasa yang berada di Pasar Terapung di wilayah Banjarmasin, Kalimantan Selatan. Pasar terapung dijadikan sebagai objek penelitian dikarenakan pasar tersebut telah menjadi pasar tradisional sejak zaman dulu dan pasar tersebut juga merupakan salah satu pasar yang menjadi ciri kebudayaan bagi suku Banjar.

\section{Metode}

Pendekatan yang digunakan peneliti dalam penelitian ini adalah pendekatan deskriptif kualitatif. Bogdan dan Miller (dalam Moleong, 2006: 3) mengemukakan bahwa penelitian kualitatif adalah penelitian yang mengahasilkan data deskriptif berupa kata-kata tertulis atau lisan dari orangorang atau perilaku yang diamati.

Pendekatan kualitatif sangat relevan dengan penelitian yang akan diteliti, dan pendekatan kualitatif digunakan dengan alasan bahwa yang menjadi fokus penelitian adalah berupa komunikasi dalam bentuk lisandi pasar terapung wilayah Banjarmasin. Pendekatan deskriptif bertujuan untuk mengumpulkan, mengklasifikasi, dan menganalisis data sehingga diperoleh gambaran penggunaan register di kalangan pedagang di Pasar Terapung Kota Banjarmasin dan mengetahui makna register di kalangan pedagang di Pasar Terapung Kota Banjarmasin. Untuk menentukan maknanya, kajian hermeneutik juga diperlukan dalam pengungkapannya.

Lokasi penelitian berada di Pasar Terapung Wilayah Banjarmasin. Penelitian ini dilaksanakan selama 3 bulan dari bulan April 2017 s.d. Juli 2017. Adapun yang menjadi data penelitian ini adalah register di kalangan pedagang di Pasar Terapung Kota Banjarmasin dan sumber datanya seperti apa yang disampaikan oleh Moleong (2006:157) bahwa sumber data utama penelitian kualitatif adalah kata-kata dan tindakan selebihnya adalah data tambahan seperti 
dokumen dan lain-lain. Jadi, data yang berupa kata-kata dikumpulkan untuk diklasifikasi serta dikelompokkan sesuai dengan apa yang ingin diteliti. Sumber datanya adalah komunikasi diantara register di kalangan pedagang di Pasar Terapung Kota Banjarmasin

Teknik pengumpulan data yang digunakan seperti diuraikan Suharsimi (1998:100) menyebutkan bahwa metode pengumpulan data adalah cara-cara yang digunakan peneliti untuk mengumpulkan data. Dalam pengumpulan data, peneliti menggunakan beberapa teknik, yaitu teknik observasi, teknik dokomentasi, teknik rekaman, dan teknik simak catat.

\section{Hasil dan Pembahasan}

\section{Penggunaan Register bentuk Nomina di Kalangan Pedagang Tradisional di Pasar Terapung}

\section{Kota Banjarmasin}

Berdasarkan hasil pengamatan peneliti di Pasar Terapung berkenaan register di kalangan pedagang, maka tergambar bentuk penggunaan register tersebut.

Komunikasi yang dilakukan oleh pembeli dan penjual di pasar terapung terdapat kata yang berbentuk nomina. Register bentuk kata yang dihasilkan berdasarkan penelitian yang dilaksanakan sebagai berikut.

(1) Limau atau jeruk

Limau atau jeruk merupakan buah yang dijual di pasar terapung. Kata limau berupa kata dasar dan diklasifikasikan nomina. Lihat kutipan percakapan 5 berikut.

Penjual : Nukari kah? Ada pisang, rempeye, limau.

Pembeli : Rempeye tu barapa haraganya Cil ?

Penjual : Ampat buting 5 ribu nak ai.

Pembeli : Kada kurang kah Cil ?

Penjual : Nah, kada kawa nak ai.

Pembeli : Ayuha nah, nukar ampat buting haja Cil ai. Tukar Cil lah.

Penjual : Iih nak ai dijual.

(2) Peyek atau Rempeyek

Peyek atau bisa juga dikatakan rempeyek merupakan salah satu makanan yang dijual di pasar terapung. Kata peyek atau rempeyek merupakan kata dasar yang diklasifikasikan nomina. Lihat kutipan percakapan 1 berikut.

Pembeli : Yang pian jual apa ja cil?

Penjual : Pisang, rempeyek

Pembeli : Pian meulah saurangkah peyeknya cil?

Penjual : Peyeknya meambil ampun urang jua

(3) Pisang

Pisang merupakan salah satu buah yang dijual di pasar terapung. Pisang adalah kata dasar yang diklasifikasikan nomina. Lihat kutipan percakapan 1 berikut. 
Pembeli : Yang pian jual apa ja cil?

Penjual : Pisang, rempeyek

Pembeli : Pian meulah saurangkah peyeknya cil?

Penjual : Peyeknya meambil ampun urang jua

(4) Pukis

Pukis merupakan salah satu kue yang dijual di pasar terapung. Pukis tersebut kata dasar yang diklasifikasikan nomina. Penggunaan kata pukis terdapat dalam percakapan di pasar terapung. Lihat kutipan percakapan 10 berikut.

Pembeli :Acil itu barapa wadainya sabuting ?

Penjual :Sapuluh ribu tiga ding ai.

Pembeli :Itu wadai apa cil?

Penjual :Tarang bulan ding ai

Pembeli :Amun itu pang wadai apa cil?

Penjual :Pukis, saribu sebuting.

Pembeli : Nukar tiga pukisnya cil ai.

Penjual : Ayuja.

(5) Wadai

Wadai merupakan penyebutan nama benda secara umumnya. Pada umumnya, kata wadai digunakan untuk menyebut benda yang bisa di makan (kue). Di pasar terapung sendiri, wadai ini diperjualbelikan. Kata wadai diklasifikasikan sebagai nomina. Lihat kutipan 3 berikut.

Pembeli : Burasnya berapa cil?

Penjual : 10 ribu tiga, kalo satunya anam ribu

Pembeli : Selain itu bajual apa lagi cil?

Penjual : Wadai, nasi kuning, nasi putih

Pembeli : Maulah sauranglah cil?

Penjual : Iih, maulah sendiri

(6) Paung

Paung merupakan penyebutan nama bibit. Kata paung ini sebagai kata yang umum dan dia diklasifikasikan nomina. Lihat kutipan percakapan 12 berikut yang terdapat penyebutan kata paung.

Pembeli : ne limau apa ngarannyacil

Penjual : limau hirisan, manis banar limaunya

Pembeli : asli mana ne cil

Penjual : asli palimadang paungnya

Pembeli : geh nukar saparu cil

Penjual : nah sama bagiannya

Pembeli : tukarcil lah

Penjual : jual 
Pais merupakan kue tradisional yang dijualbelikan di pasar terapung. Kata pais tersebut diklaifikasikan nomina. Lihat kutipan percakapan 13 berikut yang memuat kata pais.

Penjual : apa, wadai apa?

Pembeli : berapaan wadainya paman?

Penjual : dua ribuan!

Pembeli : tempe paman berapaan?

Penjual : sama ja, dua ribuan satu!

Pembeli : paman,pais paman?

Penjual : berapa buting?

Pembeli : dua!

(8) Tempe

Tempe merupakan makanan ulahan yang digoreng. Tempe ini dijual di pasar terapung yang dibarengi dengan petis. Kata tempe diklasifikasikan nomina. Adapun percakapan berkenaan dengan kata tempe ini terdapat dalam kutipan 13 berikut.

Penjual : apa wadai apa?

Pembeli : berapaan wadainya paman?

Penjual : dua ribuan!

Pembeli : tempe paman berapaan?

Penjual : sama ja, dua ribuan satu!

Pembeli : paman,pais paman?

Penjual : berapabuting?

Pembeli : dua!

Penjual : pais dua lah?

Pembeli : selain pais apa ada, tempekah paman?

Penjual : ada, apalagi?

Pembeli : tempe sebuting!

(9) Duit

Duit merupakan kata yang menunjukkan alat tukar yang sah di sebuah negara. Kata duit diklasifikan nomina. Penggunaan kata duit terletak pada kutipan percakapan 19 berikut.

Penjual : dari Alalak

Pembeli : jadi pian asli orang Alalak lah, asli Banjar?

Penjual : hiih

Pembeli : oh, parak ja lah?

Penjual : iih

Pembeli : nah ini paman duit nya bayar pisang tadi

Penjual : iih,yang ini tadi aja kah?

Pembeli : inggih

(10) Sewadahan 
Sewadahan merupakan kata berimbuhan yang berasal dari kata dasar wadah kemudian mendapatkan penambahan awalan Se- dan akhiran -an. Kata sewadahan diklasifikasikan nomina. Penggunaan kata sewadahan terletak pada kutipan percakapan 19 berikut.

Pembeli : pisangnya pang berapa paman?

Penjual : 15ribu ja yang itu

Pembeli : kalo yang teanum itu berapa?

Penjual : 20ribu yang itu, harus sewadahan jua. Handak yang mana?

Pembeli : yang 15ribu tu ja gin paman ae

Penjual : yang ini aja kah?

Pembeli : inggih

(11) Buras

Buras merupakan salah satu dari makanan tradisional masyarakat Banjar. Buras dibuat dari beras yang dibungkus dengan daun pisang, kemudian dijarang sampai masak. Kata buras diklasifikasikan nomina. Penggunaan kata buras terdapat dalam kutipan percakapan 3 berikut.

Pembeli : Burasnya berapa cil?

Penjual : 10 ribu tiga, kalo satunya anam ribu

\section{(12) Sasisir}

Sasisir merupakan kata berimbuhan yang berasal dari kata sisir, kemudian ditambahan partikel sa- yang menunjukkan satu. Kata sasisir diklasifikasikan nomina. Penggunaan kata sasisir terdapat dalam kutipan percakapan 24 berikut.

Pembeli : Barapa jua haraga pisang cil?

Penjual : 20 ribu 3 sisir nang halus. Mun yang ganal sasisir 15 ribu.

\section{(13) Gumpal}

Gumpal merupakan kata dasar yang menunjukkan benda. Gumpal adalah kue tradisional yang dijual di pasar terapung. Kata gumpal diklasifikasikan nomina. Penggunaan kata gumpal terdapat dalam kutipan percakapan 25 berikut.

Pembeli : Amang ada bajual apa haja?

Penjual : Ada wadai, ada nasi bungkus jua na ding ai. Handak nang mana nyaman aku maambil akan na?

Pembeli : Tu tahu sumpal, tempe, gumpal, pais pisang mang ai!

Penjual : Ni nasi iwaknya hintalu, hayam. Haraganya 6 ribuan sabungkus!

Pembeli : Na nasi bungkusnya 2 buting, tahu dua! Amang, gumpal tu manis kah kada kah?

Penjual : Manis ni gumpalnya ding ai!

Pembeli : Amang yang babungkus kaya pais tu lupis kah?

Penjual : Lain ding ai, bila lupis bagula habang lawan baniur. Tapi ini namanya sasunduk bila jar urang banjar.

Pembeli : Na barapa sabarataan ampun kami haraganya mang?

Penjual : 30 ribu barataan ding ai, na jual lah?

Pembeli : Tukar jua, mang ai. 
(14) Lupis

Lupis merupakan kata dasar yang menunjukkan benda. Lupis adalah kue tradisional yang terbuat dari beras ketan yang dibungkus dengan daun pisang serta dijual di pasar terapung. Kata lupis diklasifikasikan nomina. Penggunaan kata lupis terdapat dalam kutipan percakapan 25 berikut.

Pembeli : Amang ada bajual apa haja?

Penjual : Ada wadai, ada nasi bungkus jua na ding ai. Handak nang mana nyaman aku maambil akan na?

Pembeli : Tu tahu sumpal, tempe, gumpal, pais pisang mang ai!

Penjual : Ni nasi iwaknya hintalu, hayam. Haraganya 6 ribuan sabungkus!

Pembeli : Na nasi bungkusnya 2 buting, tahu dua! Amang, gumpal tu manis kah kada kah?

Penjual : Manis ni gumpalnya ding ai!

Pembeli : Amang yang babungkus kaya pais tu lupis kah?

Penjual : Lain ding ai, bila lupis bagula habang lawan baniur. Tapi ini namanya sasunduk bila jar urang banjar.

Pembeli : Na barapa sabarataan ampun kami haraganya mang?

Penjual : 30 ribu barataan ding ai, na jual lah?

Pembeli : Tukar jua, mang ai.

(15) Sasunduk

Sasunduk merupakan kata dasar yang menunjukkan benda. Sasunduk adalah kue tradisional yang terbuat dari beras ketan yang dibungkus dengan daun pisang serta dijual di pasar terapung. Kata sasunduk diklasifikasikan nomina. Penggunaan kata sasunduk terdapat dalam kutipan percakapan 25 berikut.

Pembeli : Amang ada bajual apa haja?

Penjual : Ada wadai, ada nasi bungkus jua na ding ai. Handak nang mana nyaman aku maambil akan na?

Pembeli : Tu tahu sumpal, tempe, gumpal, pais pisang mang ai!

Penjual : Ni nasi iwaknya hintalu, hayam. Haraganya 6 ribuan sabungkus!

Pembeli : Na nasi bungkusnya 2 buting, tahu dua! Amang, gumpal tu manis kah kada kah?

Penjual : Manis ni gumpalnya ding ai!

Pembeli : Amang yang babungkus kaya pais tu lupis kah?

Penjual : Lain ding ai, bila lupis bagula habang lawan baniur. Tapi ini namanya sasunduk bila jar urang banjar.

Pembeli : Na barapa sabarataan ampun kami haraganya mang?

Penjual : 30 ribu barataan ding ai, na jual lah?

Pembeli : Tukar jua, mang ai. 
Sakaranjang merupakan kata yang mendapatkan penambahan partikel $S a$ - di depannya. Sakaranjang berasal dari kata dasar karanjang kemudian diberikan penambahan partikel Samenjadi sakaranjang yang menunjukkan satu. Kata sakaranjang diklasifikasikan nomina. Penggunaan kata sakaranjang terdapat dalam kutipan percakapan 26 berikut.

Pembeli : cil saitu barapa

Penjual : 25

Peembeli ; sarangsang itu bararti 25

Penjual :iih 25

Pembeli : amun kada sarangsang pang kawa lah

Penjual : kawa barapa handak 5 biji 15 ribu

Pembeli : pisang to pang cil barapa

Penjual :Lima ribu Satu, sabuting

Pembeli : sasikat kah

Penjual :iih

Pembeli :matan jam barapa pian di sini cil ?

Penjual : matan jam 6 tadi pang, tapi sampai jam 9 habis

Pembeli : cil cil limau ngintu pang barapa

Penjual : yang ngintu 30 sakaranjang samuanya

(17) Sarangsang

Sarangsang merupakan kata yang mendapatkan penambahan partikel $S a$ - di depannya. Sarangsang berasal dari kata dasar rangsang kemudian diberikan penambahan partikel Samenjadi sarangsang yang menunjukkan satu. Kata sarangsang diklasifikasikan nomina. Penggunaan kata sakaranjang terdapat dalam kutipan percakapan 26 berikut.

Pembeli : cil saitu barapa

Penjual : 25

Peembeli ; sarangsang itu bararti 25

Penjual :iih 25

Pembeli : amun kada sarangsang pang kawa lah

Penjual : kawa barapa handak 5 biji 15 ribu

Pembeli : pisang to pang cil barapa

Penjual :Lima ribu Satu, sabuting

Pembeli : sasikat kah

Penjual :iih

Pembeli :matan jam barapa pian di sini cil ?

Penjual : matan jam 6 tadi pang, tapi sampai jam 9 habis

Pembeli : cil cil limau ngintu pang barapa

Penjual : yang ngintu 30 sakaranjang samuanya

(18) Sasikat

Sasikat merupakan kata yang mendapatkan penambahan partikel Sa- di depannya. Sasikat berasal dari kata dasar sikat kemudian diberikan penambahan partikel Sa- menjadi sasikat yang menunjukkan satu. Kata sasikat diklasifikasikan nomina. Penggunaan kata sasikat terdapat dalam kutipan percakapan 26 berikut.

Pembeli : cil saitu barapa 


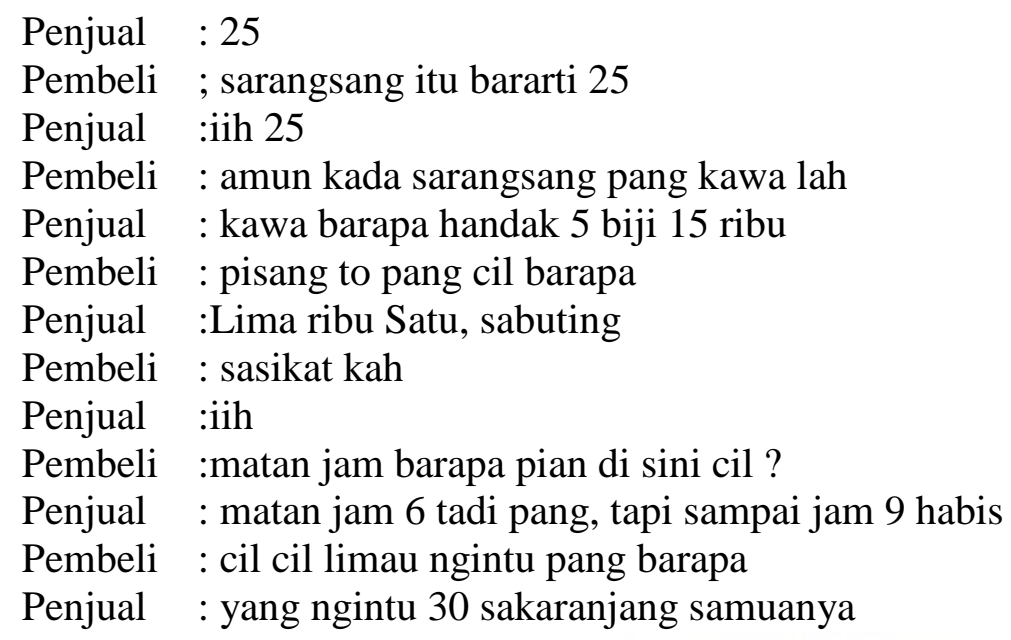

(19) Urap

Urap merupakan salah satu sayur genre tradisional yang dijual di pasar terapung. Urap tersebut diracik dengan khas Banjar. Kata urap diklasifikasikan nomina. Penggunaan kata urap terdapat dalam kutipan percakapan 4 berikut.

Pembeli : Berapa urapnya cil?

Penjual : Berapa ikm handak nungkar

Pembeli : tiga ribu kawalah?

Penjual : Kawa, banasikah?

Pembeli : Kada cil ay, urapnya ja

(20) Saikat

Saikat merupakan kata yang mendapatkan penambahan partikel Sa- di depannya. Saikat berasal dari kata dasar ikat kemudian diberikan penambahan partikel Sa- menjadi saikat yang menunjukkan satu. Kata saikat diklasifikasikan nomina. Penggunaan kata saikat terdapat dalam kutipan percakapan 26 berikut.

Pembeli : Barapa ni pian bajual limau ngini ?

Penjual : Sawadah dua puluh ribu haja $\mathrm{Cu}$ ai nah.

Pembeli : Amun pisang ambon ni pang ni ?

Penjual : Dua puluh ribu saikat $\mathrm{Cu}$ ai.

Pembeli : Umai, kada kurang kah ni ?

Penjual : Saitu pang $\mathrm{Cu}$ ai, tukari nah.

Pembeli : Handak limau tadi haja ni ai.

Penjual : Limau tu lima belas ribu haja nah $\mathrm{Cu}$ ai.

Pembeli : Nukar sawadah ja ni ai.

Penjual : Ayuha, nini tambahi nah 3 biji.

Pembeli : Inggih ni. Tukarlah.

Penjual : Jual $\mathrm{Cu}$ ai

(21) Sabuah

Sabuah merupakan kata yang mendapatkan penambahan partikel Sa- di depannya. Sabuah berasal dari kata dasar buah kemudian diberikan penambahan partikel Sa- menjadi sabuah yang 
menunjukkan satu. Kata sabuah diklasifikasikan nomina. Penggunaan kata sabuah terdapat dalam kutipan percakapan 26 berikut.

Pembeli : Barapa ni pian bajual limau ngini ?

Penjual : Sawadah dua puluh ribu haja $\mathrm{Cu}$ ai nah.

Pembeli : Amun pisang ambon ni pang ni ?

Penjual : Dua puluh ribu saikat $\mathrm{Cu}$ ai.

Pembeli : Umai, kada kurang kah ni ?

Penjual : Saitu pang Cu ai, tukari nah.

Pembeli : Handak limau tadi haja ni ai.

Penjual : Limau tu lima belas ribu haja nah $\mathrm{Cu}$ ai.

Pembeli : Nukar sawadah ja ni ai.

Penjual : Ayuha, nini tambahi nah 3 biji.

Pembeli : Inggih ni. Tukarlah.

Penjual : Jual Cu ai

(22) Tanggui

Tanggui merupakan penutup kepala khas Kalimantan Selatan. Tanggui ini digunakan oleh masyarakat Banjar ketika ingin keluar rumah atau berangkat kerja. Kata tanggui diklasifikasikan nomina. Penggunaan kata tanggui terdapat dalam kutipan percakapan 7 berikut.

Penjual : Nukar kah nak ? Ada putu mayang, rempeye jua nah.

Pembeli : Putu mayang barapa sabuting Cil ?

Penjual : Saribu sabuting. Barapa buting handak nah ?

Pembeli : Dua buting gin Cil ai nah.

Penjual : Dua ribu jadinya nak ai.

Pembeli : Yang di ujung tu nangapa namanya Cil ?

Penjual : Ngitu tanggui namanya nak ai.

\section{Penutup}

\section{Simpulan}

Berdasarkan pembahasan di atas, maka dapat disimpulkan bahwa.

1. Kata yang ditemukan berkenaan dengan register bentuk nomina, yakni; limau atau jeruk, peyek atau rempeyek, pisang, pukis, wadai, paung, pais, tempe, duit, sewadahan, buras, sasisir, gumpal, lupis, sasunduk, sakaranjang, sarangsang, sasikat, urap, saikat, sabuah, dan tanggui

2. Penggunaan register nomina di Pasar Terapung bisa menunjukkan buah, benda yang digunakan/ dipakai, dan tempat meletakkan barang.

\section{Saran}

Sebagai masukan, maka ada beberapa hal yang perlu disarankan. 
1. Masyarakat lebih memperhatikan bahasa yang digunakan dalam komunikasi di pasar terapung karena bahasa menjadi ciri khas dalam jual-beli di pasar terapung.

2. Pembahasan tentang bahasa bisa dikembangkan atau dilanjutkan lagi. Bahkan, bisa juga menggunakan subjek yang lain. Oleh karena itu, perlu peningkatan pengamatan di pasar terapung bagi peneliti lainnya nanti.

\section{Daftar Rujukan}

Alwasilah, A. Chaedar. 1993. Beberapa Madhab \& Dikotomi Teori Linguistik. Bandung: Angkasa.

Andersen, Gisle. 2001. Pragmatic Markers and Sociolinguistic Variation: A Relevance-Theoretic Approach to The Language of Adolescents. Amsterdam/Philadelphia: John Benjamins Publishing Company.

Baryadi, Praptomo. 2014. Pengembangan “Dwibahasawan yang Seimbang” Untuk Mepertahankan Bahasa-Bahasa Daerah di Indonesia. Bahasa Daerah. Banjarbaru: Balai Bahasa Provinsi Kalimantan Selatan.

Biber, Douglas dan Edward Finegan. (Eds). 1994. Sociolinguistic Perspectives on Register. New York: Oxford University Press.

Kridalaksana, Harimurti. 2011. Kamus Linguistik. Edisi Keempat. Jakarta: Gramedia.

Moleong, Lexy J. 2006. MetodologiPenelitianKualitatif. Bandung: RemajaRosdakarya.

Suharsimi, Arikunto. 1998. Prosedur Penelitian: Suatu Pendekatan Praktek. Jakarta: Rineka Cipta.

Tofa. 2013. Bahasa Daerah. (Online), (https://kangtofa.wordpress.com /2013/10/05/bahasadaerah/\#more-121). Diakses 28 April 2016. 